\title{
Resistance to thyroid hormone $\beta$ in autoimmune thyroid disease: a case report and review of literature
}

\author{
Di Wu${ }^{\dagger}$, Rui Guo ${ }^{\dagger}$, Huiling Guo, Yushu Li, Haixia Guan ${ }^{*}$ and Zhongyan Shan
}

\begin{abstract}
Background: Resistance to thyroid hormone beta (RTH $\beta$ ) results in symptoms of both increased and decreased thyroid hormone action. The effect of thyroid hormone changes in different types of autoimmune thyroid disease (AITD) in RTH $\beta$ is dynamic.

Case presentation: A 25-year-old Asian female had a RTH $\beta$ Y321C mutation with Hashimoto's thyroiditis and type 2 diabetes mellitus. She was followed-up through gestation and two years postpartum, revealing development of postpartum thyroiditis (PPT) with characteristic wide fluctuations in serum thyrotropin levels, and of spontaneous recovery from an episode of transient hypothyroidism. The presence of RTH $\beta$ did not prolong thyroiditis duration nor progressed toward permanent hypothyroidism. Prenatal genetic analysis was not performed on the unaffected fetus, and did not result in congenital hypothyroidism, possibly because maternal free thyroxine (FT4) levels were mildly elevated at less than 50\% above the reference range in early gestation and gradually decreased to less than $20 \%$ after the 28th gestational week.
\end{abstract}

Conclusion: In RTH $\beta$ patients with autoimmune thyroid disease, episodes of thyroid dysfunction can significantly alter thyrotropin levels. During pregnancy, mildly elevated maternal free thyroxine levels less than $20 \%$ above the upper limit may not be harmful to unaffected fetuses. Unnecessary thyroid hormone control and fetal genetic testing was avoided during the gestational period with monthly follow-up.

Keywords: Resistance to thyroid hormone, Autoimmune thyroid disease, Gestational monitoring

\section{Background}

Resistance to thyroid hormone (RTH) is a rare autosomal dominant condition of elevated free thyroxine (FT4) and free triiodothyronine (FT3) with non-suppressed thyrotropin (TSH) levels due to reduced sensitivity to thyroid hormone. Mutations are mostly heterogeneous in the thyroid hormone receptor $\alpha$ or $\beta$ gene causing symptoms of both increased and decreased thyroid hormone action, depending on the tissues' predominant receptor isoform expression, the magnitude of hormonal resistance, and the effectiveness of compensatory mechanisms. RTH $\beta$ accounts for

* Correspondence: hxguan@vip.126.com

†Di Wu and Rui Guo contributed equally to this work.

Department of Endocrinology and Metabolism, The Endocrine Institute and

The Liaoning Provincial Key Laboratory of Endocrine Diseases, The First

Hospital of China Medical University, 155 Nanjing Bei Street, Shenyang,

Liaoning 110001, People's Republic of China approximately $90 \%$ of RTH in which patients manifest goiter and tachycardia [1].

Autoimmune thyroid disease (AITD) is defined by the presence of thyroid autoantibodies, which is common in the general population. Graves' disease and Hashimoto's thyroiditis (HT) are forms of AITD that can cause hyperthyroidism and hypothyroidism. Physiological and immunologic changes during pregnancy and postpartum period can ameliorate and aggravate thyroid immunity, respectively, leading to postpartum thyroiditis (PPT). Transient thyroid dysfunction from AITD feedback to the impaired thyroid hormone receptors in RTH $\beta$ [2].

We present a case of RTH $\beta$ with concomittent AITD in whom the natural thyroid hormone profile was followed for 4 years, including through pregnancy and during the postpartum period. We also review the current literature on the management and outcomes of cases of RTH $\beta$ and AITD in pregnancy.

(c) The Author(s). 2018 Open Access This article is distributed under the terms of the Creative Commons Attribution 4.0 International License (http://creativecommons.org/licenses/by/4.0/), which permits unrestricted use, distribution, and reproduction in any medium, provided you give appropriate credit to the original author(s) and the source, provide a link to the Creative Commons license, and indicate if changes were made. The Creative Commons Public Domain Dedication waiver (http://creativecommons.org/publicdomain/zero/1.0/) applies to the data made available in this article, unless otherwise stated. 


\section{Case presentation}

A 25-year-old female presented with heat intolerance, palpitations, weight gain, and goiter. Thyroid function tests showed FT4 at $24.46 \mathrm{pmol} / \mathrm{L}$ (normal range, 9.01-19.05), FT3 at $7.31 \mathrm{pmol} / \mathrm{L}$ (normal range, 2.63-5.70), and TSH at $8.63 \mathrm{mIU} / \mathrm{L}$ (normal range, 0.35-4.94). Radioiodine uptake was $21.95 \%$ at $3 \mathrm{~h}$ (normal range, $10-30 \%$ ) and $41.5 \%$ at $24 \mathrm{~h}$ (normal range, $25-60 \%$ ). TSH was stimulated from 4.50 to $34.40 \mathrm{mIU} / \mathrm{L} 15 \mathrm{~min}$ after intravenous bolus of thyrotropinreleasing hormone (TRH); liothyronine (L-T3) suppressed TSH from $4.61 \mathrm{mIU} / \mathrm{L}$ to $0.21 \mathrm{mIU} / \mathrm{L}$ [3]. Pituitary magnetic resonance imaging (MRI) revealed no abnormality. Gene sequencing identified a heterozygous $\mathrm{Y} 321 \mathrm{C}$ substitution mutation in exon 9 of the THRB gene [4], thereby confirming the diagnosis of RTH $\beta$. Dual-energy X-ray absorptiometry (DEXA) scan revealed decreased bone mass. The patient was considered as susceptible to Hashimoto's thyroiditis based on positive thyroid peroxidase antibodies (TPOAb), positive thyroglobulin antibodies (TgAb), and negative thyrotropin receptor antibodies (TRAb). She was given L-T3 to suppress $\mathrm{TSH}$, and a $\beta$-blocker to manage tachycardia.

In addition, she had a history of diabetes mellitus without glucose management that resulted in hemoglobin A1c (HbA1c) at 7.1\%; oral glucose tolerance test (OGTT) showed basal glucose $7.8 \mathrm{mmol} / \mathrm{L}$ $\left(15.2 \mathrm{mmol} / \mathrm{L}\right.$ at $\left.120^{\prime}\right)$ and basal insulin $19.47 \mathrm{mIU} / \mathrm{L}$ $\left(80.87 \mathrm{mIU} / \mathrm{L}\right.$ at $\left.120^{\prime}\right)$, and homeostasis model assessment-estimated insulin resistance (HOMA-IR) was 6.75 . Her body mass index (BMI) was $28.3 \mathrm{~kg} /$ $\mathrm{m}^{2}$ at $155 \mathrm{~cm}$ height. She had liver steatosis and serum triglyceride level was $3.05 \mathrm{mmol} / \mathrm{L}$.

The patient requested ovulation induction after 2 years of irregular menstruation and infertility. The singleton pregnancy was confirmed at 13 weeks gestation, then both LT3 and $\beta$-blocker were discontinued. Her thyroid functions and fetal ultrasound morphology were monitored every 1-4 weeks (more frequently during the initial and last month), and revealed no complications. Based on the mild elevation of maternal thyroid hormones and patient preference, fetal THRB gene testing was not performed. The patient also did not require propranolol or propylthiouracil during pregnancy for RTH because she was asymptomatic and had mildly elevated and stable thyroid functions (Fig. 1). Since FT4 crosses the placenta, propylthiouracil is recommended by the Endocrine Society to decrease FT4 levels if it is too high. L-T3 was not considered since it does not cross the placenta. However, she did require strict glucose control for previously diagnosed diabetes mellitus with insulin titrated to 52 units daily towards the end of gestation (HbA1c 5.20-5.50\%). She was instructed to closely monitor her glucose levels, and she did not experience any hyper- or hypoglycemic symptoms or emergencies during pregnancy. The pregnancy was uneventful until premature rupture of membranes at 37 weeks, which developed to placental abruption during observation, and a healthy neonate of $3210 \mathrm{~g}$ was delivered by caesarean. The newborn did not have a THRB mutation. Suppressed TSH and low birth weight commonly seen in unaffected infants born to RTH mothers was not observed. The newborn

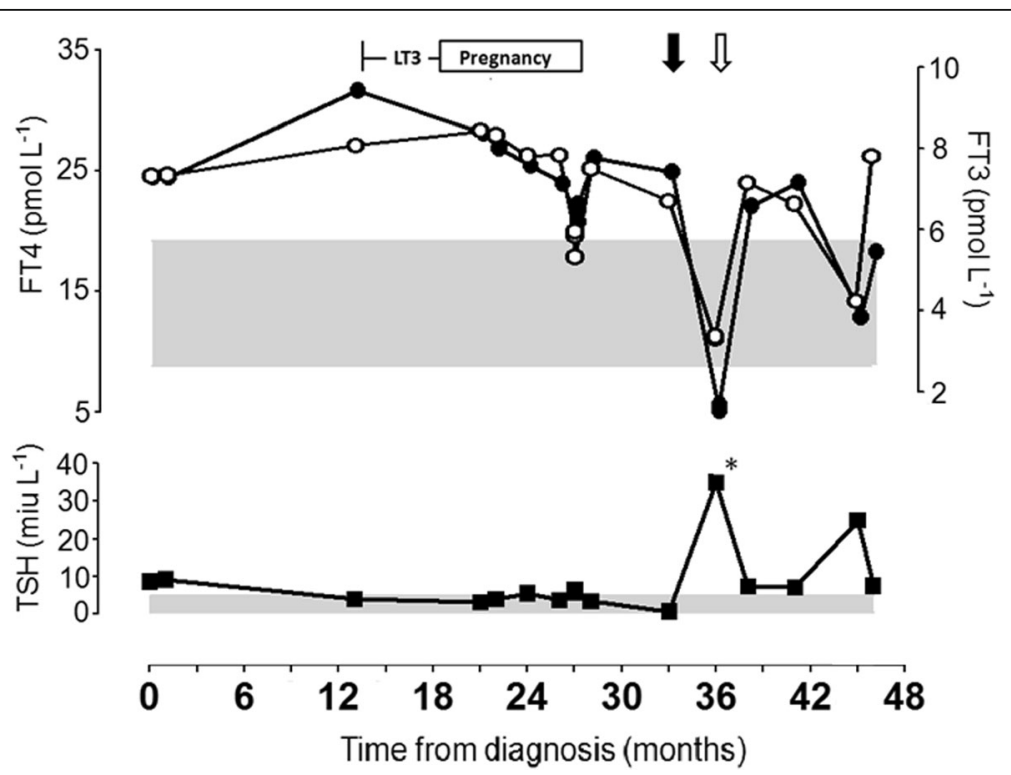

Fig. 1 Changes in thyroid function. FT4 (black circle), FT3 (white circle), and TSH (black square) were monitored in the patient diagnosed with RTH $\beta$ and autoimmune thyroiditis. The thyrotoxic phase of postpartum thyroiditis occurred 6 months after delivery (solid black arrow), followed by a hypothyroid phase at 9 months (white arrow), and the return to status quo ante at 11 months postpartum. Hypofunctioning thyroid from Hashimoto's thyroiditis occurred at 18 months postpartum, followed by spontaneous recovery after 1 month. * Indicates TSH values exceeding the instrument's upper limit: TSH > 100 mIU/L. Abbreviations: LT3, levotriiodothyronine therapy; FT4, free thyroxine; FT3, free triiodothyronine; TSH, thyrotropin 
did not show signs of thyroid dysfunction in the follow-up: FT4 was $14.47 \mathrm{pmol} / \mathrm{L}$ with $\mathrm{TSH} 5.05 \mathrm{mIU} / \mathrm{L}$ at onemonth-old, and FT4 $12.28 \mathrm{pmol} / \mathrm{L}$ with TSH $1.20 \mathrm{mIU} / \mathrm{L}$ at one-year-old. After delivery, the patient was restarted on L-T3 (low starting dose for titration), and insulin (24-26 units daily) doses were readjusted, but all medications were discontinued 1 month after delivery due to poor compliance.

At 6 months postpartum, the patient showed marked suppression of TSH compared with baseline $(0.59 \mathrm{mIU} / \mathrm{L}$ vs. 8.63 $\mathrm{mIU} / \mathrm{L})$ with elevated FT3 (6.70 pmol/L) and FT4 (24.94 $\mathrm{pmol} / \mathrm{L}$ ), but remained clinically euthyroid. HOMA-IR was 7.97 with fasting glucose at $10.12 \mathrm{mmol} / \mathrm{L}$. Suppressed TSH in RTH followed by exceedingly elevated TSH (>100 mU/L) at 9 months postpartum indicated the occurrence of PPT, which recovered at 11 months postpartum (Fig. 1). Fasting glucose and insulin varied between 8 and $12 \mathrm{mmol} / \mathrm{L}$ and 17.5-21.8 $\mathrm{mIU} / \mathrm{L}$, respectively. HOMA-IR during the hypothyroid phase could not be calculated from medical charts. Glycemia was managed with diet and exercise, though controlled less ideally compared to prepregnancy.

At 18 months postpartum, the patient was asymptomatic apart from discomfort due to a III degree goiter. $\mathrm{TSH}$ were again elevated, but recovered spontaneously after 1 month suggesting an episode of Hashimoto's thyroiditis. No medication was prescribed for this period.

The index member's biological mother had a history of poorly-controlled Graves' disease, and diabetes mellitus.
She was later found to carry the same THRB mutation. THRB gene sequencing of the index case's spouse and father were negative for mutation. Second-degree relatives reported no symptoms related to thyroid dysfunction, and thyroid function screening was normal without inappropriate TSH secretion, however, they declined gene sequencing.

\section{Discussion and conclusions}

We observed the natural fluctuations in thyroid hormone levels of RTH $\beta$ under the influence of gestational physiology and autoimmune thyroiditis. Table 1 reviews the literature of the management and outcomes of RTH $\beta$ pregnancies with and without AITD.

Unnecessary thyroid medication was avoided during the gestational period with frequent 1-4 week follow-ups in our patient. However, no recommendations has been made to suggest even more frequent follow-up intervals are needed for RTH mothers to unaffected fetuses [3]. On the other hand, the Endocrine Society recommends that FT4 levels should be maintained at less than $20 \%$ above the reference range in RTH mothers carrying unaffected fetus [3]. Although the FT4 levels in our patient reached the recommended levels only after the 28th gestational week, this did not result in congenital hypothyroidism in the unaffected fetus, possibly because maternal FT4 levels were mildly elevated at less than 50\% above the reference range in early gestation and gradually decreased throughout pregnancy.

Table 1 Literature review of RTH $\beta$ and AITD in pregnancy

\begin{tabular}{|c|c|c|c|c|c|}
\hline Author & $\begin{array}{l}\text { RTH } \beta \\
\text { THRB } \\
\text { mutation }\end{array}$ & AITD Thyroid antibodies & Gestational management for RTH $\beta$ & $\begin{array}{l}\text { Maternal } \\
\text { outcome }\end{array}$ & Foetal outcome \\
\hline $\begin{array}{l}\text { Jonas et } \\
\text { al. } 2014 \text { [5] }\end{array}$ & $\begin{array}{l}\text { R320C } \\
(C 1243 C> \\
T)\end{array}$ & $\begin{array}{l}\text { Hashimoto's thyroiditis: } \\
\text { TPOAb and TgAb } \\
\text { positive, TRAb negative. }\end{array}$ & $\begin{array}{l}3 \text { pregnancies. Levothyroxine (LT4) } \\
\text { to maintain an fT4 range within } \\
20 \% \text { of the upper limit of normal. } \\
\text { No chorionic villous sampling. }\end{array}$ & $\begin{array}{l}\text { Uneventful } \\
\text { pregnancies. } \\
\text { Developed } \\
\text { postpartum } \\
\text { thyroiditis (PPT). }\end{array}$ & $\begin{array}{l}\text { Full-term neonates had normal birth } \\
\text { weights and body lengths. The first child } \\
\text { harboured the THRB mutation. }\end{array}$ \\
\hline $\begin{array}{l}\text { Paragliola } \\
\text { et al. } 2013 \\
\text { [10] }\end{array}$ & $\begin{array}{l}\text { V283A } \\
(g .361470 \\
T>C) \text { on } \\
\text { exon } 8\end{array}$ & $\begin{array}{l}\text { TPOAb and TgAb } \\
\text { positive, TRAb negative. }\end{array}$ & $\begin{array}{l}2 \text { pregnancies. Monthly monitoring } \\
\text { of her thyroid function. Did not } \\
\text { require any treatment }\end{array}$ & $\begin{array}{l}\text { Uneventful } \\
\text { pregnancies. } \\
\text { Developed PPT } \\
\text { after pregnancies. }\end{array}$ & $\begin{array}{l}\text { Full-term male neonates with normal } \\
\text { birth weights and normal thyroid } \\
\text { function. }\end{array}$ \\
\hline $\begin{array}{l}\text { Boix et al. } \\
2007[11]\end{array}$ & $\begin{array}{l}\text { M310 V } \\
\text { on exon } 9\end{array}$ & $\begin{array}{l}\text { latrogenic } \\
\text { hypothyroidism after } \\
\text { radioiodine treatment } \\
\text { for autoimmune } \\
\text { hyperthyroidism }\end{array}$ & $\begin{array}{l}\text { Triiodothyronine (LT3) to maintain } \\
\text { normal TSH. Unsuccessful } \\
\text { amniocentesis for RTH testing. }\end{array}$ & $\begin{array}{l}\text { Uneventful } \\
\text { pregnancy }\end{array}$ & $\begin{array}{l}36 \text { week unaffected male neonate with } \\
\text { normal birth weight. }\end{array}$ \\
\hline $\begin{array}{l}\text { Furlanetto } \\
\text { et al. } 2000 \\
\text { [12] }\end{array}$ & $\begin{array}{l}\text { M310L } \\
(928 A>T) \\
\text { on exon } 9\end{array}$ & TPOAb negative. & - & $\begin{array}{l}\text { Uneventful } \\
\text { pregnancy. }\end{array}$ & $\begin{array}{l}\text { Full-term affected female neonate with } \\
\text { length } 46 \mathrm{~cm}(5-10 \text { th percentile), and } \\
\text { weight } 2250 \mathrm{~g} \text { ( }<5 \text { th percentile). } \\
\text { Elevated thyroid function. }\end{array}$ \\
\hline $\begin{array}{l}\text { Sarkissian } \\
\text { et al. } 1999 \\
\text { [13] }\end{array}$ & $\begin{array}{l}\text { T329 } \mathrm{N} \text { on } \\
\text { exon } 9\end{array}$ & $\begin{array}{l}\text { Antithyroid, anti-T4 and } \\
\text { anti-T3 antibodies were } \\
\text { negative. }\end{array}$ & $\begin{array}{l}\text { Dextrothyroxine (DT4) therapy was } \\
\text { discontinued upon pregnancy. }\end{array}$ & $\begin{array}{l}\text { Five spontaneous } \\
\text { abortions. }\end{array}$ & $\begin{array}{l}35 \text { week unaffected male neonate with } \\
\text { normal weight and normal thyroid } \\
\text { function. } 38 \text { week affected female } \\
\text { neonate weight } 2850 \mathrm{~g} \text { and length } 47 \\
\mathrm{~cm} \text { (height/Age at }-2 \mathrm{SD} \text { compared to } \\
\text {-1SD in both parents, and body mass } \\
\text { index of } 12.9 \text { at the fifth percentile for } \\
\text { age). }\end{array}$ \\
\hline
\end{tabular}


In addition, the value of fetal gene analysis was small as maternal thyroid hormone levels gradually decreases in pregnancy, thus making the fetal growth environment reasonably less toxic. This decline in thyroid hormone levels during pregnancy is common, and should be taken into account for affected mothers to avoid overtreatment. Lack of prenatal genetic analysis on the unaffected fetus did not result in congenital hypothyroidism in our patient and other reported cases [5]. RTH $\beta$ did not prolong PPT or transient thyroiditis disease duration or progression toward permanent hypothyroidism.

Barkoff et al. [6] determined an increased prevalence of AITD among RTH- $\beta$ patients, and postulated that susceptibility to AITD may be due to an underlying genetic disposition. Our subjects have shown that in first-degree relatives the variation in type of AITD phenotype under RTH- $\beta$ is present; RTH- $\beta$ with HT, and RTH- $\beta$ with GD. Moreover, the natural progression of AITD is independent of inherent $\mathrm{RTH}$, the development of PPT and spontaneous recovery from follicular damage in HT, the presence of RTH- $\beta$ did not increase disease duration or progression toward permanent hypothyroidism.

Another observation is that glucose metabolism is independent of TFT results, in this case family, DM was diagnosed in the two members with genetically-confirmed RTH- $\beta$. Currently, the prevalence of DM in RTH patients is unknown. Apart from significantly higher insulin resistance and lower insulin sensitivity in RTH- $\beta$ patients than control subjects as observed by Mitchell et al. [7], the relationship between $\mathrm{TH}$ and blood glucose in RTH- $\beta$ remains undetermined. In our patient, the most dramatic change in $\mathrm{TH}$ occurred during the hypothyroid phase of PPT (Fig. 1), at which basal glucose and insulin was still comparable to baseline levels, indicating that RTH- $\beta$ may also blunt the effect of significant TH fluctuation on insulin resistance. Furthermore, the management of one condition might be able to alleviate another. Stagi et al. [8] proposed that TRIAC therapy might alleviate hyperinsulinism and improve insulin resistance after one year. $\mathrm{Al}$ though it is unclear whether these drug responses are clinically significant in the majority of RTH- $\beta$ patients [9], it is important to note that the extent of dominant-negative effect in mutant TH receptors and the degree of islet cell dysfunction in diabetes disease course for each individual is different.

This case report highlights an important issue of whether initiating pharmacologic treatment in RTH $\beta$ condition is always needed during pregnancy. In cases where FT4 levels are mildly elevated and decreasing throughout pregnancy and where prenatal genetic testing is not performed, it is advisable to adopt an attentive and cautious monitoring and care. This case report supports that conservative approach can have a positive outcome without harming the RTH $\beta$ mother and the unborn unaffected fetus.

\section{Abbreviations}

AITD: Autoimmune thyroid disease; DEXA: Dual-energy X-ray absorptiometry; FT3: Free triiodothyronine; FT4: Free thyroxine; HT: Hashimoto's thyroiditis; LT3: Liothyronine or 3,5,3'-Levo-triiodothyronine; MRI: Magnetic resonance imaging; PPT: Postpartum thyroiditis; RTH: Resistance to thyroid hormone; TgAb: Thyroglobulin antibodies; TPOAb: Thyroid peroxidase antibodies; TRH: Thyrotropin-releasing hormone; TSH: Thyrotropin, or thyroid stimulating hormone

\section{Acknowledgements}

Not applicable.

Funding

Not applicable.

Availability of data and materials

Data sharing is not applicable to this article as no datasets were generated or analysed during the current study.

\section{Authors' contributions}

DW, HG and ZS analyzed and interpreted the data. DW and HG wrote the manuscript. RG and HG performed the thyroid hormone function measurements and patient follow-up. DW, HG and YL researched the literature. $H G, Y L$ and $Z S$ revised the manuscript critically for important intellectual content. All authors read and approved the final manuscript.

Authors' information

Not applicable.

\section{Ethics approval and consent to participate}

This case report was approved by the Ethics Committee of the First Affiliated Hospital of China Medical University. Written consent was obtained from the patient for publication of study.

\section{Consent for publication}

The patient consented to the publication of this study, knowing that the manuscript may include potentially identifying information.

Competing interests

The authors declare that they have no competing interests.

\section{Publisher's Note}

Springer Nature remains neutral with regard to jurisdictional claims in published maps and institutional affiliations.

Received: 26 August 2017 Accepted: 21 November 2018

Published online: 03 December 2018

\section{References}

1. Refetoff S, Bassett JH, Beck-Peccoz P, Bernal J, Brent G, Chatterjee K, De Groot LJ, Dumitrescu AM, Jameson JL, Kopp PA, et al. Classification and proposed nomenclature for inherited defects of thyroid hormone action, cell transport, and metabolism. J Clin Endocrinol Metab. 2014;99(3):768-70.

2. Taniyama M, Otsuka F, Tozaki T, Ban Y. Thyroid profiles in a patient with resistance to thyroid hormone and episodes of thyrotoxicosis, including repeated painless thyroiditis. Thyroid. 2013;23(7):898-901.

3. Weiss RE, Dumitrescu A, Refetoff S. Approach to the patient with resistance to thyroid hormone and pregnancy. J Clin Endocrinol Metab. 2010;95(7):3094-102.

4. Adams M, Matthews C, Collingwood TN, Tone Y, Beck-Peccoz P, Chatterjee KK. Genetic analysis of 29 kindreds with generalized and pituitary resistance to thyroid hormone. Identification of thirteen novel mutations in the thyroid hormone receptor beta gene. J Clin Invest. 1994;94(2):506-15.

5. Jonas C, Daumerie C. Conservative management of pregnancy in patients with resistance to thyroid hormone associated with Hashimoto's thyroiditis. Thyroid. 2014;24(11):1656-61.

6. Barkoff MS, Kocherginsky M, Anselmo J, Weiss RE, Refetoff S. Autoimmunity in patients with resistance to thyroid hormone. J Clin Endocrinol Metab. 2010;95(7):3189-93.

7. Mitchell CS, Savage DB, Dufour S, Schoenmakers N, Murgatroyd P, Befroy D, Halsall D, Northcott S, Raymond-Barker P, Curran S, et al. Resistance to thyroid 
hormone is associated with raised energy expenditure, muscle mitochondrial uncoupling, and hyperphagia. J Clin Invest. 2010;120(4):1345-54.

8. Stagi S, Manoni C, Cirello V, Covelli D, Giglio S, Chiarelli F, Seminara S, de Martino M. Diabetes mellitus in a girl with thyroid hormone resistance syndrome: a little recognized interaction between the two diseases. Hormones (Athens). 2014;13(4):561-7.

9. Brenta G, Schnitman M, Fretes O, Facco E, Gurfinkel M, Damilano S, Pacenza N, Blanco A, Gonzalez E, Pisarev MA. Comparative efficacy and side effects of the treatment of euthyroid goiter with levo-thyroxine or triiodothyroacetic acid. J Clin Endocrinol Metab. 2003;88(11):5287-92.

10. Paragliola RM, Concolino P, De Rosa A, Mello E, Zuppi C, Pontecorvi A, Capoluongo E, Corsello SM. The first case of association between postpartum thyroiditis and thyroid hormone resistance in an Italian patient showing a novel p.V283A THRB Mutation. Thyroid. 2012;23(4):506-10.

11. Boix E, Pico A, Zapico M, Lopez A, Mauri M. Outcome of pregnancy in a hypothyroid woman with resistance to thyroid hormone treated with triiodothyronine. J Endocrinol Investig. 2007;30(3):253-5.

12. Furlanetto TW, Kopp P, Peccin S, Gu WX, Jameson JL. A novel mutation (M310L) in the thyroid hormone receptor beta causing resistance to thyroid hormone in a Brazilian kindred and a neonate. Mol Genet Metab. 2000;71(3):520-6.

13. Sarkissian G, Dace A, Mesmacque A, Bony-Trifunovic H, Malezet-Desmoulins C, Torresani J, Margotat A. A novel resistance to thyroid hormone associated with a new mutation (T329N) in the thyroid hormone receptor beta gene. Thyroid. 1999;9(2):165-71.

Ready to submit your research? Choose BMC and benefit from:

- fast, convenient online submission

- thorough peer review by experienced researchers in your field

- rapid publication on acceptance

- support for research data, including large and complex data types

- gold Open Access which fosters wider collaboration and increased citations

- maximum visibility for your research: over $100 \mathrm{M}$ website views per year

At $\mathrm{BMC}$, research is always in progress.

Learn more biomedcentral.com/submissions 